\title{
Distance Learning, Emergency Remote Online Teaching and Symbolic Interaction Theory During COVID-19: Implications for Education in Nigeria
}

\author{
Edih, O. University ${ }^{1 *}$, Umuze, N. Anthonia $^{2}$, and Fagawari, D. Nyanayon ${ }^{3}$ \\ ${ }^{1}$ Marine Economics, Nigeria Maritime University Okerenkoko Delta State, Nigeria. \\ ${ }^{2}$ Mass Communication, Delta State Polytechnic, Ugwashi-uku, Delta State, Nigeria. \\ ${ }^{3}$ Port Management, Nigeria Maritime University Okerenkoko Delta State, Nigeria. \\ *Corresponding Author E-mail: oweilade123uni@gmail.com
}

Received 3 January 2022; Accepted 23 February 2022; Published 25 February 2022

\begin{abstract}
The paper examined the impact of symbolic interaction theory on distance learning and/or emergency remote online teaching during Covid'19 pandemic. The objective of the study is to ascertain whether it is practicable to implement symbolic interaction model in distance learning and teaching methodology. Data were generated through questionnaire administered to 200 participants selected from three study centers of NOUN (National University of Nigeria). Questionnaire was designed in Likert scale of five (strongly agreed) to one (strongly disagreed). Data were analyzed using frequencies, percentages, mean, standard deviation, $t$-test and one-way ANOVA. Findings showed that the manifest benefits of symbolic interaction in classroom teaching were not evident in online education. More so, the technological environment and other infrastructure required for implementing distance learning and/or emergency remote online teaching were grossly lacking in Nigeria. The paper recommended that government and private institutions should collaborate in creating enabling technological environment for the implementation of emergency remote online education to complement face to face teaching during crisis period.
\end{abstract}

Keywords: Covid-19, distance learning, Nigeria, online education, symbolic interaction

\section{INTRODUCTION}

The drums of corona-virus disease are still raging and manifesting in diverse variants. Its sound does not respect persons, countries and continents. Developed and developing countries are affected by this deadly pandemic. Deaths of its victims are recorded in all continents in the world. As at 15 August, 2020, about $21,026,758$ people representing $27 \%$ of the world population (7.8 billion) were confirmed victims of the viral disease (Covid-19) (WHO,2020; Worldometer, 2020). Its consequences are notorious and devastating. Socioeconomic and political activities have been gravely distorted. This has necessitated a paradigm shift in planning and procedures in governance/or management of state/or organizations in the world.
Soludo (2020) referred to this paradigm slip in philosophies, methodologies, partnerships as creative destruction. To worsen the situation, governments in many countries imposed lockdown on international and local travels (air ports were closed temporarily), schools, markets and sporting activities (football and other games) were put on hold. Lives are threatened seriously because no cure has been discovered. Covid-19 pandemic caught the world like whirl fire and a prolonged lockdown will aggravate the ailing socio-economic situations (Edih, Salami and Fagawhari, 2020). Due to the closure of schools, pupils, students, undergraduates have stopped attending schools for the past six or seven months. Covid-19 pandemic has caused unprecedented socio- 
economic crises in the world (Giorgio, Hilligje and Trine, 2020). Lockdown of educational institutions is the worse form of human slavery and deprivation (Edih et al., 2020). United Nations reported that more than 170 million learners were affected by schools and universities closures (Paolo and Andrea, 2020).

The tragic health pandemic has altered the hitherto narratives, traditional methods of managing things in all continents. It is a common denominator to all challenges; economic, political and socio-cultural affinities in the world. The impact of coronavirus on education has made governments and private institutions to think towards adopting emergency online education (Giorgio, 2020). Indeed, lockdown and social distancing mechanisms had adversely impacted on educational studies in the world. On 1 April, 2020, 1,542,412,000 students, constituting $89.4 \%$ of total enrolled learners in schools and higher education institutions were closed in 185 countries (UNESCO Report; Giorgio et al., 2020).

Due to the consequences of Covid-19 outbreak, teaching and learning processes have shifted from the classroom (face-to-face) to distance learning and/or emergency remote online learning. This compulsory shift is beset with myriad of challenges such as access to technical infrastructures, competences and pedagogies, specific learning requirements, environment factors etc (Giorgio et al., 2020). However, in developed nations, there may be contingency plans to mitigate these solvable challenges but, a double tragedy in developing countries hitherto plagued with compounded educational problems (Odia, 2007). Despite these impediments to distance learning, governments and educational institutions are considering online education being a viable recourse in crisis period (CDC, 2019; www.werforum-org/agenda2020). Distance education (distance learning) is attracting patronage due to time and restriction of face-to-face learning system. These restrictions have been exacerbated by the viral outbreak of pneumonia popularly called Covid-19 (Filiz and Mustafa, 2012).

This paper is contending that distance learning or emergency remote online teaching does not exhibit the core attributes of classroom teaching and learning reinforced by symbolic interaction theory. The concepts of distance learning, distance education and emergency remote online learning have been discussed and defined according to authors' perspectives/or contexts in several studies. It thus portrays that there is no universal definition of distance or remote online learning but sister nomenclatures which drive a common goal (Fredrick, Michael and Kelly, 2004). It is on this premise that these semantically related concepts may be applied interchangeably in this paper.

The study is aimed at examining the application of symbolic interaction theory in distance learning/or emergency remote online education in Nigeria. It will also evaluate the need to establish emergency remote online educational institutions during pandemic and consider the challenges confronting distance learning in Nigeria. The paper is focused on the educational situation in Nigeria during Covid-19 pandemic. Data collected was restricted to NOUN (National Open University of Nigeria) being symbolic of distance learning institution. Based on the foregoing context, some research questions are yearning for answers: can distance learning and/or emergency remote online teaching be undertaken in Nigeria? Are there infrastructures for distance learning in Nigeria? Can the manifest benefits of classroom be teaching feasible in distance learning? Are the principles of symbolic interaction practicable in emergency online education? Are there teachers in distance learning pedagogies in Nigeria? The findings in this study will assist policy makers in formulating relevant educational policies for the country.

\section{Review of literature}

\section{Distance Learning, Distance Education and Emergency Remote Online Teaching: A Semantic Discourse}

Fredrick et al. (2004) made some distinctions and relationships between distance learning and distance education in his study entitled "defining distance learning and distance education. We wish to examine and replicate some of their perspectives in this paper. The authors critiqued the definitions propounded by United Stated Distance Learning Association, USDLA (Roblyer and Edwards, 2000). USDLA (1998) define distance learning as "the acquisition of knowledge and skills through mediated information and instruction encompassing all technologies and other forms of learning at distance". They failed to separate formal education from informal learning as well as the types of distance either temporal or physical (Federick et al., 2004). In similar context, Newby, Stepich, Lehman and Russell (2000) define distance learning as "an organized instructional program in which teachers and learners are physically separated". Fredrick et al. (2004) discovered some flaws or omissions in this definition. Newby et al. (2000) definition only presumed the existence of a program without actual learning.

In the opinion of Fredrick et al. (2004) distance learning is an improved capability in knowledge and/or behaviors as a result of mediated experiences that are constrained by time and/or distance such that the learner does not share situation with what is being learned". The authors also proffered that "distance education is a formalized instructional learning where time/geographic situation constrains learning by not affording in-person contact between students and instructor". Filiz and Mustafa, (2012) also define distance learning in line with USDLA (1998) definition as "an organizational framework and 
process of providing instruction at a distance" while distance education as educational relationship between teacher and students who are physically separated but bridged together by technology. The above definitions of distance learning and distance education tend to illustrate a learning process between teacher/or instructor and students who are separated by distance. This educational partnership is mediated through information technologies. The arrangement may be formal or informal; however, in the context of this paper, we are considering formal educational model.

Emergency remote teaching is a concept coined by Charles, Stephanie, Barb, Torrey and Aaron. (2020). The clause 'emergency remote teaching' will be an elusive expression disconnected from online or distance education if the word 'online' is not co-opted into it to represent emergency remote online teaching. The definition of emergency remote online teaching cannot be exact as emergency remote teaching under thorough academic scrutiny. However, Charles et al. (2020) see emergency remote teaching as a branch of online education. It is the learning process that evolves during crisis. An extension of distance learning or education with teaching methodologies devised to offer instruction to students in emergent periods.

Online education simply means online process of teaching and learning which may not be totally different from distance learning or education. Complexities in these conceptualizations are purely semantic dynamics. Contextually, online researchers and professional practitioners differ in the use of the word teaching, education, learning or instruction. This is rather based on choice of words (Charles et al., 2020). Emergency remote online teaching is therefore, teaching pedagogies or instructions delivered by teachers to students through information technology in abnormal or pressing circumstances. That is why it is an emergent type of education designed for a defined period. Therefore, Covid-19 pandemic, being a global emergency is not an exception.

\section{Challenges of Emergency Remote Online Teaching in Nigeria}

Distance education and/or emergency remote online teaching may be a rewarding experience to undergraduates in higher education based on their maturity but strange bed fellow to learners in primary and secondary schools. Charles et al. (2020) argued that teaching and learning flexibility is enhanced through online education. However, the narrow preparation window during crises impedes quality delivery of instructional materials. They also posit that, comparing online learning to face-to-face teaching in a pandemic state was a great temptation and juxtaposing distance learning and class-room lectures could amount to a political debate. Regrettably, graduates or credentials awarded from online education institutions attract societal stigma than their counterparts from conventional higher education system. Graduates from the National Open University of Nigeria (NOUN), particularly, Law graduates are being discriminated by the Nigerian Law School (NLS). Nigerian Law School has refused to admit them for the one-year professional training on Legal Advocacy. Hope this misunderstanding is resolved in favour of NOUN law graduates!

Before the advent of Covid-19 pandemic, public institutions in Nigeria were in a comatose state, however, salvaged/or complemented by private institutions with exorbitant tuitions fees only affordable to wealthy families. Public institutions were besieged with ceaseless strikes embarked on by ASUU (Association of Staff of Universities Union), SSANU (Senior Staff Association of Nigerian Union) and sister bodies at the primary and secondary education strata. Odia (2007) laid credence to the remote causes of these avoidable and manorchestrated industrial actions. Among the numerous problems are infrastructural deficit, poor funding, lack of teachers' welfare and non-implementation of peaceful agreement reached with labour unions. This has resulted to uncontrollable brain-drain for greener pastures outside the shores of Nigeria.

The outbreak of Covid-19 crisis revealed the structural weaknesses in the educational sector in Nigeria. Teaching technologies and infrastructural materials for classroom learning and demonstration are grossly lacking. Nigerians have been calling on government to declare a 'state of emergency' on the education sector. Currently, staff of federal universities' is on strike amidst Covid-19 pandemic because of the aforementioned mountainous problems retarding educational growth in the country.

Based on this premise, online education is a hard nut to crack in Nigeria. The National Open University of Nigeria (NOUN), whose law graduates have not been recognized by Nigerian Law School, is the only University that may be classified as semi-distance learning institution in the country. NOUN operational pedagogies are (partly) resemblance of distance education. Interactions between teachers (facilitators) and students are mediated by instructional materials properly packaged in modules. Students are only opportune to see their facilitators to explain grey areas in their courses a month to semester's examination. Globally, 770 million learners are claimed to be affected by schools and universities closure. Due to this closure, home schooling and online tutorials are on the rise. Studies showed that, Home-schooling supervised by parents have shown quality and long term outcomes (Heckman, 2006 cited in Paolo and Andrea, 2020). Paolo and Andrea (2020) also contended that access to on-line education was not universal. About 80 million people in China lacked internet connection or a web enabled device in 2018. Reports equally showed 
that $10 \%$ of households in UK have no internet connection. It is worst in developing countries.

A debatable argument is that, the installation of technological inclined educational environment to facilitate online learning requires appreciable time. Charles et al. (2020) corroborated that effective online education required capital investment and time to identify relevant strategies for its establishments. Arguably, insincerity and politics in government are grievous impediments to this plausible vision. Edih et al. (2020,) had argued that corruption, insincerity and politics were major hindrances to educational growth in Nigeria. More so, online or distance learning is more practicable for learners in higher education and face-to-face teaching reinforced by symbolic interaction theory is more convenient for learners in primary and secondary education. This means that online education is a partial solution (category of learners) to educational needs of a country.

\section{Symbolic Interaction Theory}

Symbolic interaction has been described as a process of interpretation of actions. Objects or events do not have relevance or meanings until interpretative symbols are ascribed to them. It is also one of the theories in social sciences that is relevant in explaining the influence of teachers on students in educational environment and a veritable source of data in human communication (Nilgun, Buket, Mufit and Symera, 2012). The emphasis of symbolic interaction is the communication of meanings of ideas, concepts, philosophies and events or objects through the assignment of symbols and labels that pass messages to the audience. This may facilitate the audience interpretation and understanding. Since the context of this discourse is on formal education, our review is centered on classroom demonstrations, perceptions, performances, attitudes and interactions between teachers and students.

George Herbert Mead, a professor of University of Chicago in 19922 synchronized his philosophical, sociological and psychological ideas into a pragmatic theory to explain the influence of social actors (human beings) on the social environment (Loulla, 2012). However, these ideas or philosophies were popularized by his student Blumer in 1969. Blumer contended that meanings are ascribed to ideas and events through interaction process. He opined that symbolic interaction is based on three critical ideas such as: interaction between actors and the world, dynamics of the actor and social environment, and actor's competence in studying and interpreting and understanding the world (Loulla, 2012).

The thought of Mead (Symbolic interactionism) was published in a book titled 'Mind, self and Society' after his death in 1931. The theory portrays the influence of social environment (i.e social structures, classes, power and its abuse) on people's personalities (Brewster, 2013).
This demonstrates a cyclical dynamic between actors and the world. In similar vein, Sharon (2004) identified five central ideas to symbolic interaction, namely; human beings are thinkers, human beings define their situations, human actions are caused by prevailing circumstances, human beings are social persons and they are active in relations to the environment. The basis of these themes is to establish constant and progressive interactions between social actors and surrounding environment.

Snow also suggested four basic orienting principles to explain symbolic interaction theory. These are, human agency (human as social and active agents in the society), interactive determination (through interactions, meanings, identities, roles and practices are conceived or determined), symbolization (act of creating symbols to ideas or events while events, conditions; artifacts, people and other environmental factors symbolize or mean something to the actors) and emergency (dynamics in society creates the possibility of new forms of social life and system meanings and emerging transformations) (Reynolds and Nancy, 2013).

With references to classroom interactions and interpretations of concepts or events, teachers and students are the social actors. The teachers give instructions to students, evaluate their perceptions, performance and grade their results. The continuous interplay between teachers and students in the school environment synthetically mould the characters or attitudes of the students. Through the combination and understanding of other learning theories namely; cognitivism (thinking and problem-solving), constructivism propounded by Vygotsky in 1978 (the more knowledgeable other- teacher, the zone of proximal development and social interactions), pedagogy (formal teaching method) and andragogy (informal teaching approaches) and pragmatism developed by John Dewey (1859-1952)( Learning is life and formal school is failing and falling short of its potentials), students' learning ability, receptiveness, interpretative skills and teachersstudents relationships would be improved. However, the attributes of symbolic interaction between teachers (the more knowledgeable other, MKO) and students is totally lacking in online education or emergency remote online teaching. So what do we do during pandemic? Should we only pass knowledge without moulding character? Teachers are supposed epitome of exmplary character to students and if they can't set their eyes on these role models, how will they pattern their behaviours? This is the gap between teachers (instructors) and students in online education. How do we bridge this gap?

\section{MATERIALS AND METHODS}

The only semi-distance learning institution in Nigeria is NOUN (National Open University of Nigeria) with multiple study centers. The study considered three campuses in 
Table 1: Descriptive statistics on demography and opinions about distance or emergency online teaching.

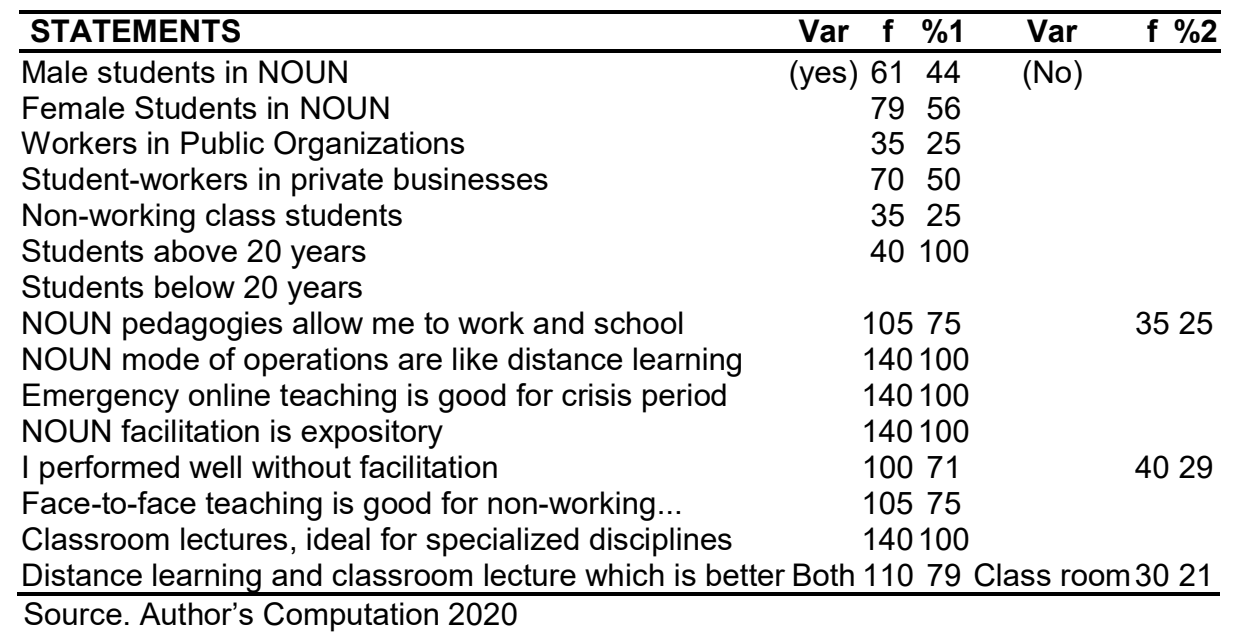

Asaba, Benin and Warri. Non-random sampling technique was used for the collection of data from 200 participants. Primary data were sourced through email (being a pandemic period/lockdown of study centers) and 140 questionnaires were returned representing $70 \%$ rate of return. Questionnaires were designed according to Likert scale interval of five (strongly agreed) to one (1) strongly disagreed. Frequencies, percentages, mean and standard deviation, T-test and one way Anova Analyses were performed to detect respondents' differential opinions on distance learning, emergency remote online teaching and face-to-face learning reinforced by symbolic interaction ideology. Statistical analysis was patterned according to Filiz and Mustafa (2013) study.

\section{RESULTS AND DISCUSSION}

The result of data analysis on demography, statements on distance learning and/or emergency remote online teaching and face-to-face learning are presented in tables. Result from (Table 1) on demographic data showed that majority of the respondents were female students $(56 \%)$. An indication that, more females are attending NOUN. Among the respondents 105 (75\%) are working class and $35(25 \%)$ are non-working students. Working class entails current employees of public institutions and private corporations. All participants were above the age of 20 indicating maturity. The 40 respondents agreed that emergency online teaching was good for crisis period because of its importance to nation building. However, face to face teaching was better for non-working students, primary and secondary learners. Classroom lectures were equally suitable for specialized disciplines. On the debate whether distance learning, is better than classroom teaching or vice versa, respondents were divided in their opinions. 110 respondents representing $79 \%$ supported the view that both media of learning were complementary while only $21 \%$ affirmed that classroom lecture was better (views of the non-working class students). Filiz and Mustafa (2012) laid credence to face to face method of learning as a better learning method.

Results from (Table 2) showed that distance learning and/or emergency remote online teaching were modern interventions in education that were applauded. Respondents were of the views that, through good governance and gradual implementation online education was possible. However, 30 or more respondents disagreed because of distrust, politics and corruption in Nigerian government. Author (2001) contend that the bane of retardation in the education sector was politics, insincerity and corruption of the ruling class. The majority of the respondents agreed that information technology and manpower were measures for successful implementation of distance education in Nigeria. Results also indicated that communication between teachers and students were rare (crux of the study) and society stigma on credentials got from distance learning institutions were waning, may be due to knowledge and exposure. How do we incorporate Symbolic Interaction ideas into online education since teachers and students are separated by distance? Filiz and Mustafa (2012) provided solution through the use of modern information media, email, telephone, online chat and at times, face to face, teachers and students could interact. Lack of these facilities may hamper communication among social actors in the learning environment. Paulo and Andrea (2020) submitted that access to online education was not universal and that in 2018, over 80 million people lacked internet connection or web enabled device. What is, therefore the fate of developing countries?

Table 3 revealed that both gender [male and female] agreed on the use of information technology in the 
Table 2: Means and standard deviation for statements about distance learning and/or emergency online teaching.

\begin{tabular}{lcc}
\hline STATEMENTS & $\mathrm{M}$ & $\mathrm{SD}$ \\
\hline Distance learning or online learning is modern inventory in education & 4.28 & 0.79 \\
Gradual implementation is possible & 3.42 & 1.59 \\
Good governance is needed & 4.15 & 1.34 \\
Manpower is a prerequisite & 4.63 & 0.81 \\
Information ltechnological environment is ideal & 4.20 & 1.37 \\
Communication with facilitator is rare & 4.42 & 0.49 \\
Examinations are both computer based and pen-on-paper & 4.54 & 0.81 \\
Stigma on online credentials is waning & 4.14 & 0.35 \\
\hline
\end{tabular}

Source: Author's Computation 2020

Table 3: T-test between gender and measures for implementing emergency online teaching.

\begin{tabular}{lcccc}
\hline STATEMENTS & M & SD & t-test & P \\
\hline Information and technological environment & & & & \\
Male & 3.88 & 1.18 & -1.47 & 0.136 \\
Female & 4.15 & 0.95 & -1.43 & \\
Manpower On ICT Education & & & & \\
Male & 3.80 & 1.23 & -2.49 & 0.015 \\
Female & 4.23 & 0.84 & -2.36 & \\
\hline
\end{tabular}

Source. SPSS Version 20 Result Output

Table 4: One-way ANOVA between working status and statement on distance or online learning and face to face teaching.

\begin{tabular}{|c|c|c|c|c|}
\hline Distance learning is preferred to face-to-face teaching: & $\mathbf{M}$ & SD & $\mathbf{F}$ & $\mathbf{P}$ \\
\hline Working class & 1.94 & 0.73 & 2.072 & 0.152 \\
\hline Not working class & 2.14 & 0.64 & & \\
\hline \multicolumn{5}{|c|}{ Distance or Emergency online is working class designed for matured learners: } \\
\hline Working class & 4.03 & 1.28 & 23.77 & 0.000 \\
\hline Not working class & 2.71 & 1.67 & & \\
\hline
\end{tabular}

Source; SPSS Version20 Result output

implementation of online education in Nigeria. The mean of their assertions was not significantly different as $0.136>0.05$ at $95 \%$ confidence interval which showed there was no deviation from the mean. However, the response on ICT manpower requirement for online teaching was significantly different as $0.015<0.05$ at $95 \%$ confidence interval across gender. In that case, information technology and manpower in ICT education are paramount to distance learning and emergency remote online teaching. Filiz and Mustapha (2012) and Paolo and Andrea (2020) were supportive of information technology and access to internet as measures that would facilitate online education.

Results from (Table 4) indicated the opinions of respondents on preference of distance learning or face to face teaching method of education. 105(75\%) respondents [both working and non-working class] disagreed with the statement distance learning was preferred to face-to-face teaching while $35(25 \%)$ respondents were undecided. This point to the fact that, comparing distance learning with classroom lectures was needless. Charles et al (2000) canvassed that comparing both methods of teaching and learning amounted to a political debate or stage drama. On the other hand, the participants representing $79 \%$ of respondents agreed that distance or online education was preferable for matured learners (tertiary education) as revealed in the result of analysis of mean variance between the groups. There is a significant difference in opinions of working class and non-working as to whether online education is designed for matured learners as $0.00<0.05$ at $95 \%$ confidence interval. Majority of participants are matured learners who attend NOUN as also shown by (Table 1).

\section{Conclusion and implications}

This paper demonstrated an expository discourse on the semantic composition and unintended elusiveness in defining distance learning, distance education, emergency remote teaching, emergency remote online teaching viz-a-viz the application of symbolic interaction theory in online education. Symbolic interaction theory suggests that meanings are ascribed to objects, events, 
concepts, ideas, etc through interactions between the more knowledgeable other (teachers, instructors,) and students who are the social actors in the learning environment. The inherent characteristics of symbolic interaction theory are manifest in face-to-face learning environment (formal education) than in distance or online education.

Symbolic interaction may be elusive or absent to instructors and students in emergency remote online (teaching induced by pandemic) because there may be no arrangements for facilitated lectures as it obtains at NOUN. The possible media of disseminating knowledge (instructions) in distance learning/or education are usually electronic and correspondences. Students' understanding is better enhanced through purposeful interactions between teachers-students and students-students because concepts or events derive meanings through the existence of situations. Nilgun et al. (2009) centered that symbolic interaction emphasizes social interaction, debates and defines roles for people. However, the assertion of Federick et al. (2004) holds water, 'that the adoption of Phidippides to learn (correspondence courses) or mercury methods (electronic media) is to communicate instructions to students and the definitions of distance learning or emergency remote online teaching/or education apply to all teaching media'. The consequence of Covid-19 on education in Nigeria will be endemic if alternative measures to classroom teaching are not taken. Education is the way of life and life itself. Information is knowledge and power. Pandemic must not stop the functioning of educational institutions being a formalized means of transmitting knowledge from generation to generation. Therefore, every medium designed to transmit knowledge should be fashioned to accommodate positive and progressive interactions between teachers and learners.

We discovered that, the emergence of Covid-19 crises led to the closure of schools all over the world. The closure of educational institutions was total and devastating to human capital development because there were no distance learning institutions/or emergency remote online teaching to supplement classroom education during the pandemic in Nigeria.

Based on the above context, the paper recommends the following measures:

1. Government should create an enabling environment for distance learning or emergency remote online teaching by investing in information technology and developing manpower in ICT tailored towards online education.

2. Distance learning and/or emergency remote online teaching pedagogies should be designed to accommodate teachers and students' interactive sessions. NOUN (National Open University of Nigeria) has a month interactive session before semester's examinations. Distance learning institutions should recruit more manpower situate in study centers in the country. This will articulate a complementary blend between distance education and symbolic interaction theory.

3. Government and private organizations should also recognize degree awarded by distance learning institutions. This measure would help to eradicate the societal stigma on online credentials and boost student's enrolment in institutions established for online education.

\section{ACKNOWLEDGMENTS}

We are grateful to National Open University of Nigeria for her immense support in providing access details that enabled us to contact the participants for the study. We also thank Evangel Computer Press Asaba for her typesetting services. We wish to declare that the study was not sponsored and had no conflict of interest.

\section{Authors contributions}

The study was carried out by three authors. Author Edih, U.O, conceived the research topic, and drafted the introduction and review of literature. Author Umuze, N. Anthonia, and Author Fagawari, D.N. read the manuscript, summarized the abstract and conclusion. All authors read and approved the final manuscript for publication.

\section{REFERENCES}

Brewster, K. (2013) Beyond Classic Symbolic Interactionism. Towards an Intersectional of George H. Mead's Mind, Self and Society. American Sociological Association. Conference papers:1-20-vid Soc INDEX with Full test.

CDC (2020). Available online: https:

//who.int/emergencies/diseases/novel-coronavirus-2020) assessed 11 May 2020.

Charon, J. M. (2004). Symbolic Interactionism: An Introduction, An Interpretation, An Integration. Boston: Pearson p.31.

Edih, U. O., Salami, C. and Fagawari, N.D (2020). Impact of Covid'19 pandemic on educational institutions in Nigeria: looking for measures before reopening schools (in press) Public Policy and Administration

Filiz, A. K, and Mustafa, G. (2012). A Research about Distance Education Student's Satisfaction with Education Quality at an Accounting Program. Elsevier.Doi: 101016/j.sbsprom 2012.05.556.

Frederick, B. K., Michael, F. Y., and Kelly, D. (2004). Defining Distance Learning and Distance Education. Educational Technology Review.

Giorgio, M., Hilligje, V. L and Trine, J (2020). The Impact of Covid-19 on Higher Education around the World. IAU Global Survey Report.

Loulla, M. (2012). Symbolic Interactionism and Moral Hazards in Higher Education. Mooere. Vol. 2 Issue 2 Doi.10.5929/2012/2.2.2.3.

Newby, T. J., Stepich, D. A. Lehman, J. D and Russell, J. D (2000). Instruction Technology for Teaching and Learning. Upper saddle RIver, NJ; Merrill.

Nilgun, A., Buket, K., Mufit, A., and Sumeyra, D. (2019). Symbolic 
Interaction Theory. Elsevier, Doi.10. 1016.j. sbspro.2009.01.160.

Odia.

L.

$$
\text { O. }
$$$$
\text { and }
$$

Omofunmwan,

$\mathrm{S}$.

(2007). Educational Systems in Nigeria;

Prospects. Doi. 10./808/09718347.

Paolo, S., and Andrea, G (2020) The Economics of a Pandemic; The Case of Covid -19.

Reynolds, L. T, and Nancy, J. (2013). Handbook of Symbolic Interactionism. Walnut Creek, Calif: AltaMira Press. OCLC 51059349.

Roblyer, M. D, and Edwards, J. (2000). Integrating Educational Technology into Teaching (2nd edition) Upper Saddle River, NJ. Merrill.
Soludo, C (2020). Can Africa Afford Covid-19 Lock down. Retrieval online; www. Prosheareng.com $>$ new $>$ com. Africa-Covid-19lockdown. April 24/2020.

Vygotsky, L.S (1978). Mind and Society: The Development of Higher Mental Processes. Cambridge MA; Harvard University Press.

World Health Organization WHO (2020) Covid-19 report.

Worldoeter (2020) Report on World Population online www. wferforumorg/agenda-2020. 